\title{
BMJ Open Macrophage migration inhibitory factor polymorphism and the risk of ulcerative colitis and Crohn's disease in Asian and European populations: a meta-analysis
}

\author{
Ning-Bo Hao, ${ }^{1}$ Ya Fei He, ${ }^{1}$ Gang Luo, ${ }^{1}$ Xin Yong, ${ }^{1}$ Yao Zhang, ${ }^{2,3}$ Shi-Ming Yang ${ }^{1,4}$
}

To cite: Hao N-B, He YF, Luo G, et al. Macrophage migration inhibitory factor polymorphism and the risk of ulcerative colitis and Crohn's disease in Asian and European populations: a meta-analysis. BMJ Open 2013;3:e003729.

doi:10.1136/bmjopen-2013003729

- Prepublication history for this paper is available online. To view these files please visit the journal online (http://dx.doi.org/10.1136/ bmjopen-2013-003729).

$\mathrm{N}-\mathrm{BH}$ and YFH contributed equally.

Received 7 August 2013 Revised 21 November 2013 Accepted 29 November 2013

CrossMark

For numbered affiliations see end of article.

Correspondence to Professor Shi-Ming Yang; shimingyang@yahoo.com

\section{ABSTRACT}

Objective: To determine whether macrophage migration inhibitory factor (MIF) gene polymorphism is associated with the risk of inflammatory bowel disease (IBD).

Design: System review and meta-analysis. Methods: MEDLINE, EMBASE, Web of Science databases, Cochrane Library and the Chinese Biomedical Literature database (CBM) were searched for the case-control trails for MIF and IBD. All the studies included in this manuscript met the inclusion and exclusion criteria. An OR analysis using a $95 \% \mathrm{Cl}$ was employed to assess the association of the MIF-173 G/C polymorphism with IBD susceptibility.

Results: There was a significant association between the MIF-173 G/C gene polymorphism and IBD in the total population under the recessive model (CC vs GC $+\mathrm{GG} ; \mathrm{OR}=1.75, \mathrm{Cl} 1.04$ to $2.95, \mathrm{p}=0.04$ for heterogeneity) and the codominant model (CC vs GG; $\mathrm{OR}=1.74, \mathrm{Cl} 1.02$ to $2.97, \mathrm{p}=0.04$ for heterogeneity). In the stratified analysis by ethnicity, significantly increased risks were observed for Asians using the recessive $(\mathrm{OR}=1.75, \mathrm{Cl} 1.04$ to $2.95, \mathrm{p}=0.04$ for heterogeneity) and codominant models $(\mathrm{OR}=1.74$, $\mathrm{Cl} 1.02$ to $2.97, p=0.04$ for heterogeneity). Within the subgroups of $U C$ and $C D$, significant differences were observed regarding UC using the recessive $(O R=1.60$, $\mathrm{Cl} 1.09$ to $2.35, p=0.02$ for heterogeneity) and codominant models $(\mathrm{OR}=1.64, \mathrm{Cl} 1.12$ to $2.41, \mathrm{p}=0.01$ for heterogeneity). In the stratified analysis by ethnicity for UC, significant differences were observed regarding $\mathrm{CC}$ in Asians vs $\mathrm{GC}+\mathrm{GG}(\mathrm{OR}=1.73, \mathrm{Cl} 1.02$ to 2.94, $\mathrm{p}=0.04$ for heterogeneity).

Conclusions: The meta-analysis suggested that the MIF-173 G/C polymorphism contributed to the susceptibility of IBD. When considering the subgroups of ethnicity and $U C$ and $C D$, the results suggested that the polymorphism is more significant for UC in Asians.

\section{INTRODUCTION}

Inflammatory bowel disease (IBD) currently represents one of the most common health problems worldwide. The highest incidence

\section{Strengths and limitations of this study}

A large number of patients were concluded in this manuscript, which is important when examining the association between migration inhibitory factor (MIF) and inflammatory bowel disease (IBD).

- All the articles included in this manuscript must conform that all controls were in Hardy-Weinberg equilibrium.

- It still needs to demonstrate that MIF gene polymorphism was associated with IBD in other places such as Africa and South and North America.

rates and prevalence of ulcerative colitis (UC) and Crohn's disease (CD) have been reported in northern Europe, the UK and North America. ${ }^{1}$ In addition, in low-incidence areas, such as Asia, southern Europe and most developing countries, rates also continue to rise. ${ }^{2}$ However, the aetiology and pathogenesis are still unknown.

Our current understanding of IBD is a complex disease with a number of contributing factors, such as genetic predisposition, environmental factors, intestinal microbial flora and an aberrant immune response. ${ }^{1}$ It has been demonstrated that many patients with IBD have a dysregulated intestinal mucosal T-cell-mediated immune response, specifically involving CD4 T helper type-1 (Th1) lymphocytes, which leads to the production of Th1-associated proinflammatory cytokines, such as interferon $\gamma($ IFN $\gamma)$, interleukin (IL)-2 and tumour necrosis factor $\alpha$ (TNF $\alpha){ }^{3}$

In addition, another cytokine, macrophage migration inhibitory factor (MIF), is considered to play a critical role in immunity and inflammation. MIF is secreted by a series of immune cells, such as macrophages, dendritic cells, lymphocytes, neutrophils and pituitary cells. ${ }^{45}$ Once secreted, MIF regulates a broad range of immune and inflammatory activities, including the induction of inflammatory 
cytokines, such as TNF $\alpha$, IFN $\gamma$, IL-1 $\beta$, IL-12, IL-6 and CXCL8 (also known as IL-8), among others. ${ }^{6}$ However, if the MIF gene is mutated, it will disturb the immune balance in the microenvironment. It has been demonstrated that MIF gene mutation is associated with many autoimmune diseases, such as rheumatoid arthritis, glomerulonephritis and inflammatory bowel diseases. ${ }^{7-11}$ MIF genotyping studies have focused on the -794CATT- ${ }_{(5-8)}$ microsatellite and the MIF-173 G/C polymorphism. ${ }^{12}$ Donn et al ${ }^{13}$ first reported that the MIF-173 polymorphism is a risk factor for juvenile idiopathic arthritis. Consequently, Baugh $e t \mathrm{al}^{14}$ reported the association between the -794 CATT $_{(5-8)}$ microsatellite and disease severity in patients with rheumatoid arthritis. In addition, it has also been reported that the MIF gene polymorphism is a risk factor for other immune diseases, such as atrophy, asthma and sarcoidosis in patients with erythema nodosum. ${ }^{12}$ Therefore, it is important to explore whether MIF gene polymorphisms are associated with IBD. However, the research results are not in agreement. Thomas and colleagues found that there was no significant difference between patients with IBD and controls with the MIF gene type. ${ }^{15}$ In other articles, the MIF gene polymorphism has been reported to be a risk factor for IBD. ${ }^{16}{ }^{17}$ Because most of the articles on MIF gene polymorphisms and IBD studied the MIF-173 G/C polymorphism, we performed a meta-analysis to determine whether the MIF-173 G/C polymorphism is a risk factor for IBD. Our analysis reveals that the MIF-173 G/C polymorphism is a risk factor for IBD, especially for UC in Asians.

\section{MATERIALS AND METHODS}

\section{Search strategy}

This meta-analysis followed the proposal of the Meta-analysis Of Observational Studies in Epidemiology (MOOSE) group and was performed by searching PubMed, EMBASE, Web of Science databases, Cochrane Library and the Chinese Biomedical Literature database (CBM; last search updated in April 2013). ${ }^{18}$ The search strategy included the following terms: (macrophage migration inhibitory factor [MeSH] or MIF [TEXT WORD] and inflammatory bowel disease $[\mathrm{MeSH}]$ or ulcerative colitis [TEXT WORD] or Crohn's disease [TEXT WORD] or IBD [TEXT WORD] or UC [TEXT
WORD] or CD [TEXT WORD]). Searches also included scanning reference lists in relevant articles and conference proceedings as well as correspondence with authors when additional data were required. Two reviewers (N-BH and YFH) independently screened the titles and abstracts of each identified reference and categorised articles based on the full text to evaluate their eligibility for inclusion.

\section{Inclusion and exclusion criteria}

The inclusion criteria for primary studies were as follows: (1) the article evaluated MIF gene polymorphisms and IBD risk; (2) the article included case-control studies or a nested case-control study; (3) the article supplied the number of individual genotypes for the MIF polymorphisms in IBD cases and controls and (4) the article demonstrated that the distribution of genotypes among controls was in Hardy-Weinberg equilibrium (HWE). In addition, the following exclusion criteria were used. The studies were excluded when (1) it did not provide detailed data such as presented in abstracts, meeting reports and reviews; (2) the studies were repeated or that overlapped other publications; (3) the genotype frequency was not reported and (4) the controls do not meet the assumptions for HWE.

\section{Data extraction}

No article was included if it did not meet the four inclusion criteria. When the same study results appeared in several articles, only one study was used in this meta-analysis. Table 1 lists the characteristics of the extracted data, including the first author's name, publication date, region of study, ethnicity of the sample population, number of genotypes and the total number of cases and controls. The study regions included China, Japan, Spain, Germany and Poland. Data extraction was independently performed by two individuals (N-BH and YFH), and any disagreement was resolved by consensus or by consultation with additional reviewers ( $\mathrm{YZ}$ and S-MY).

\section{Qualitative assessment}

Quality assessment was performed with the NewcastleOttawa quality assessment scale (NOS) for case-control studies. A 'star system' was used to judge data quality

Table 1 Characteristics of studies included in meta-analysis

\begin{tabular}{llllllll}
\hline First author & Years & Country & Ethnicity & $\begin{array}{l}\text { Case } \\
\text { number }\end{array}$ & $\begin{array}{l}\text { Control } \\
\text { number }\end{array}$ & $\begin{array}{l}\text { Newcastle-Ottawa } \\
\text { score }\end{array}$ & Genotyping \\
\hline Griaga & 2007 & Germany & European & 259 & 489 & $7 / 9$ & PCR-RFLP \\
Shiroeda & 2010 & Japan & Asian & 111 & 209 & $6 / 9$ & PCR-SSCP \\
Fei & 2008 & China & Asian & 99 & 142 & $9 / 9$ & PCR-RFLPtetra-primer ARMS \\
Oliver & 2007 & Spain & European & 1295 & 887 & $8 / 9$ & PCR-RFLP \\
Przybyłowska & 2011 & Poland & European & 99 & 123 & $6 / 9$ & PCR-RFLP \\
Nohara & 2004 & Japan & Asian & 221 & 438 & $7 / 9$ & PCR-RFLPPCR-SSCP \\
\hline
\end{tabular}


based on three broad perspectives: selection, comparability and outcome of interest for case-control studies. Star counts were totaled to compare the study quality in a quantitative fashion. ${ }^{19}$ Based on these criteria, the content validity was evaluated by $\mathrm{N}-\mathrm{BH}$ and $\mathrm{YFH}$, and any disagreement was resolved via discussions between N-BH and GL or with the other authors (YZ S-MY) for adjudication.

\section{Statistical analysis}

All statistical tests were performed using Revman V.5.0 software. Deviations from HWE were calculated for the control groups by $\chi^{2}$ goodness-of-fit. The association between the MIF-173G/C gene polymorphism and IBD was compared by the OR and the corresponding $95 \%$ CI between the case and control groups. The statistical significance of the summary OR was determined with the $\mathrm{Z}$ test, and $\mathrm{p}$ valueless than 0.05 was considered as statistically significant. The genetic models evaluated for the polymorphism were the dominant model $(\mathrm{GC}+\mathrm{CC}$ vs $\mathrm{GG}$ ), the recessive model (CC vs GC+GG), the allelic gene model ( $\mathrm{C}$ vs $\mathrm{G}$ ) and the codominant model ( $\mathrm{CC}$ vs GG and GC vs GG).

The heterogeneity between studies was determined by the $\chi^{2}$-based $Q$ test. A $p$ value greater than 0.05 for the Q-test indicated a lack of heterogeneity among the studies. If there was a lack of heterogeneity, the pooled OR estimate of each study was calculated using a fixed-effects model (the Mantel-Haenszel method); otherwise, a random-effects model (the DerSimonian and Laird method) was used..$^{20}$ In addition, subgroup analysis stratified by ethnicity and different disease types was also performed. The potential publication bias was estimated by a funnel plot. Egger's linear regression test on the natural logarithm scale of the OR was used to assess the funnel plot asymmetry; the significance was set at the $\mathrm{p}<0.05$ level. $^{22}$

\section{RESULTS}

\section{Study characteristics}

Figure 1 outlines our search process. First, a total of 123 articles were collected after the initial search with the key words listed previously. After reading the title and abstract, 12 reviews and 1 editorial were excluded. Next, 99 articles were excluded for no association with IBD and the MIF-173 G/C polymorphism. The remaining 11 articles were identified for full-text review and 4 articles were excluded because of repeated publications. In addition, 1 article was excluded because it deviated from HWE. ${ }^{23}$ Finally, six articles met our inclusion criteria and were used for the meta-analysis with 2084 cases and 2288 controls. $^{15-17}$ 24-26 The basic characteristics of these articles are listed in table 1 . Of the eligible studies, $3 / 6$ articles researched the association of the MIF-173 gene polymorphism with $\mathrm{UC}$ and $\mathrm{CD}$. The remaining 3 / 6 articles researched only the association of the MIF-173 $\mathrm{G} / \mathrm{C}$ polymorphism with UC. In total, $3 / 6$ studies were

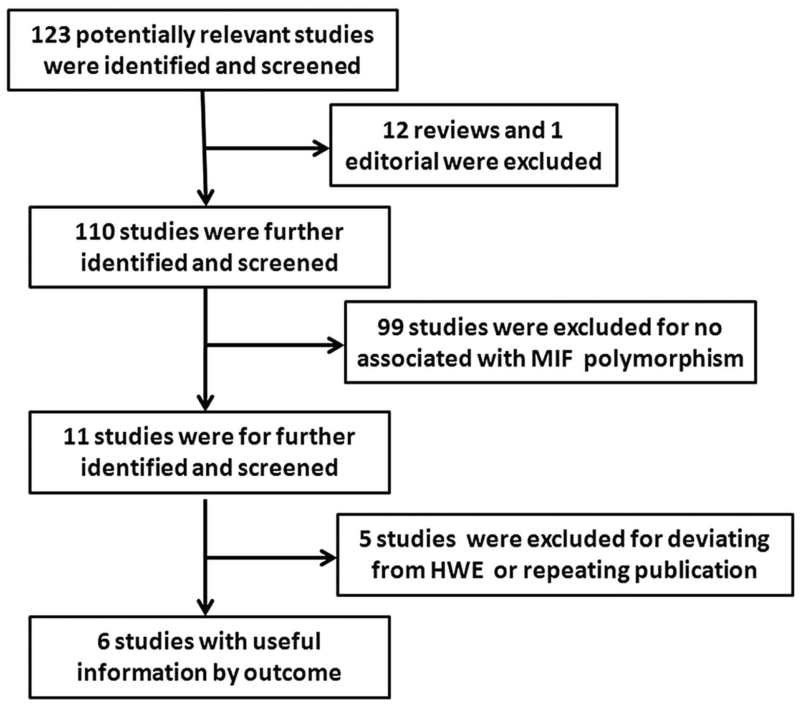

Figure 1 Flowchart of the study identification, inclusion and exclusion.

performed in Europeans and 3/6 studies were performed in Asians. All studies were cross-sectional casecontrol studies with sufficient data to calculate the possible relationship between the MIF-173 G/C polymorphism and IBD. All studies were published in English. The distribution of the MIF-173 gene type in IBD, UC and $\mathrm{CD}$ is listed in table 2.

\section{Quantitative data synthesis}

Table 3 lists the primary results. In the total population, we found a significant difference between the MIF-173 $\mathrm{G} / \mathrm{C}$ gene polymorphism and the risk of IBD for two variants: $\mathrm{CC}$ vs $\mathrm{GC}+\mathrm{GG}(\mathrm{OR}=1.5$, CI 1.07 to $2.14, \mathrm{p}=0.02$ for heterogeneity) and CG vs GG (OR=1.54, CI 1.09 to 2.24, $\mathrm{p}=0.01$ for heterogeneity; figure $2 \mathrm{~A}-\mathrm{D}$ ). No significant difference was observed for the variants of GC+CC vs GG, GC vs GG or the allele $\mathrm{C}$ vs $\mathrm{G}$ (table 3 ).

In the stratified analysis by ethnicity, a significantly increased risk was observed in Asians for $\mathrm{CG}$ vs $\mathrm{GC}+\mathrm{GG}$ ( $\mathrm{OR}=1.75$, CI 1.04 to $2.95, \mathrm{p}=0.04$ for heterogeneity) and $\mathrm{CC}$ vs $\mathrm{GG}(\mathrm{OR}=1.74$, CI 1.02 to $2.97, \mathrm{p}=0.04$ for heterogeneity; figure 2A,B). However, no significant difference was observed in Europeans for $\mathrm{CC}$ vs $\mathrm{GC}+\mathrm{GG}$ ( $\mathrm{OR}=1.36$, CI 0.86 to $2.15, \mathrm{p}=0.19$ for heterogeneity) or $\mathrm{CC}$ vs GG (OR=1.42, CI 0.89 to 2.24, $\mathrm{p}=0.14$ for heterogeneity).

Because IBD includes UC and CD, we determined whether the role of the MIF-173 G/C gene polymorphism was different between the two diseases. Therefore, we analysed subgroups of UC and CD. Significant differences were observed in $\mathrm{UC}$ for $\mathrm{CC}$ vs $\mathrm{GC}+\mathrm{GG}(\mathrm{OR}=1.60$, CI 1.09 to $2.35, p=0.02$ for heterogeneity) and $\mathrm{CG}$ vs $\mathrm{GG}$ $(\mathrm{OR}=1.64$, CI 1.12 to $2.41, \mathrm{p}=0.01$ for heterogeneity; figure 2C,D). However, no significant differences were found in $\mathrm{CD}$ for $\mathrm{CC}$ vs $\mathrm{GC}+\mathrm{GG}(\mathrm{OR}=1.41$, CI 0.85 to 
Table 2 Genotypes and allele frequencies of MIF-173G/C genes in patients and controls

\begin{tabular}{|c|c|c|c|c|c|c|c|c|c|c|c|c|c|}
\hline \multirow[b]{2}{*}{ Author } & \multirow[b]{2}{*}{ Year } & \multicolumn{5}{|c|}{ Case } & \multicolumn{5}{|c|}{ Control } & \multirow[b]{2}{*}{ Sample size } & \multirow[b]{2}{*}{ HWE (P) } \\
\hline & & $\overline{\mathbf{G G}}$ & GC & CC & $\mathbf{G}$ & C & $\overline{\mathbf{G G}}$ & GC & CC & $\mathbf{G}$ & C & & \\
\hline \multicolumn{14}{|l|}{ IBD } \\
\hline Fei & 2008 & 52 & 32 & 15 & 136 & 62 & 79 & 55 & 8 & 213 & 71 & 99/142 & 0.70 \\
\hline Griaga & 2007 & 188 & 67 & 4 & 443 & 75 & 318 & 156 & 15 & 792 & 186 & $259 / 489$ & 0.43 \\
\hline Nohara & 2004 & 135 & 76 & 10 & 346 & 96 & 288 & 134 & 16 & 710 & 166 & $221 / 438$ & 0.93 \\
\hline Shiroeda & 2010 & 69 & 37 & 5 & 175 & 47 & 126 & 76 & 7 & 328 & 90 & $111 / 209$ & 0.27 \\
\hline Przybyłowska & 2011 & 66 & 31 & 2 & 163 & 35 & 99 & 23 & 1 & 221 & 25 & $99 / 123$ & 0.79 \\
\hline Oliver & 2007 & 907 & 343 & 45 & 2157 & 433 & 681 & 188 & 18 & 1550 & 224 & $1295 / 887$ & 0.24 \\
\hline \multicolumn{14}{|l|}{ UC } \\
\hline Fei & 2008 & 44 & 27 & 13 & 115 & 53 & 79 & 55 & 8 & 213 & 71 & $84 / 142$ & 0.70 \\
\hline Griaga & 2007 & 72 & 28 & 2 & 172 & 32 & 318 & 156 & 15 & 792 & 186 & $102 / 489$ & 0.43 \\
\hline Nohara & 2004 & 135 & 76 & 10 & 346 & 96 & 288 & 134 & 16 & 710 & 166 & $221 / 438$ & 0.93 \\
\hline Oliver & 2007 & 441 & 171 & 22 & 1053 & 215 & 681 & 188 & 18 & 1550 & 224 & $634 / 887$ & 0.24 \\
\hline Przybyłowska & 2011 & 38 & 19 & 1 & 95 & 21 & 99 & 23 & 1 & 221 & 25 & $58 / 123$ & 0.79 \\
\hline Shiroeda & 2010 & 69 & 37 & 5 & 175 & 47 & 126 & 76 & 7 & 328 & 90 & $111 / 209$ & 0.27 \\
\hline \multicolumn{14}{|l|}{ CD } \\
\hline Fei & 2008 & 8 & 5 & 2 & 21 & 9 & 79 & 55 & 8 & 213 & 71 & $15 / 142$ & 0.70 \\
\hline Griaga & 2007 & 116 & 39 & 2 & 271 & 43 & 318 & 156 & 15 & 792 & 186 & $157 / 489$ & 0.43 \\
\hline Oliver & 2007 & 466 & 172 & 23 & 1104 & 218 & 681 & 188 & 18 & 1550 & 224 & $661 / 887$ & 0.24 \\
\hline Przybyłowska & 2011 & 28 & 12 & 1 & 68 & 14 & 99 & 23 & 1 & 221 & 25 & $41 / 123$ & 0.79 \\
\hline
\end{tabular}

Table 3 Summary of different comparative results

\begin{tabular}{|c|c|c|c|c|c|c|c|c|c|c|}
\hline \multirow[b]{2}{*}{ Study } & \multicolumn{2}{|c|}{ Sample size } & \multirow{2}{*}{$\begin{array}{l}\text { Number of } \\
\text { studies }\end{array}$} & \multicolumn{3}{|l|}{ Test of association } & \multirow[b]{2}{*}{ Model } & \multicolumn{3}{|c|}{ Heterogeneity } \\
\hline & Case & Control & & OR (95\% Cl) & $\mathbf{Z}$ & p Value & & $\overline{\chi^{2}}$ & p Value & $I^{2}(\%)$ \\
\hline \multicolumn{11}{|c|}{$\mathrm{GC}+\mathrm{CC}$ vs $\mathrm{GG}$} \\
\hline Overall & 2084 & 2288 & 6 & 1.15 (0.87 to 1.52$)$ & 0.97 & 0.33 & $\mathrm{R}$ & 17.04 & 0.004 & 71.0 \\
\hline Asian & 431 & 789 & 3 & $1.12(0.88$ to 1.44$)$ & 0.90 & 0.37 & $\mathrm{~F}$ & 0.90 & 0.64 & 0.0 \\
\hline European & 1653 & 1499 & 3 & $1.23(0.70$ to 2.14$)$ & 0.71 & 0.48 & $\mathrm{R}$ & 15.75 & 0.0004 & 87.0 \\
\hline UC & 1210 & 2288 & 6 & 1.24 (1.06 to 1.44$)$ & 2.76 & 0.006 & $\mathrm{~F}$ & 9.69 & 0.08 & 48.0 \\
\hline CD & 874 & 1641 & 4 & 1.13 (0.69 to 1.87$)$ & 0.49 & 0.62 & $\mathrm{~F}$ & 11.46 & 0.009 & 74.0 \\
\hline \multicolumn{11}{|c|}{$\mathrm{CC}$ vs $\mathrm{GC}+\mathrm{GG}$} \\
\hline Overall & 2084 & 2282 & 6 & 1.51 (1.07 to 2.14 ) & 2.34 & 0.02 & $\mathrm{~F}$ & 6.72 & 0.24 & 26.0 \\
\hline Asian & 431 & 789 & 3 & 1.75 (1.04 to 2.95$)$ & 2.10 & 0.04 & $\mathrm{~F}$ & 2.21 & 0.33 & 9.0 \\
\hline European & 1653 & 1499 & 3 & $1.36(0.86$ to 2.15$)$ & 1.31 & 0.19 & $\mathrm{~F}$ & 4.16 & 0.12 & 52.0 \\
\hline UC & 1210 & 2288 & 6 & 1.60 (1.09 to 2.35$)$ & 2.42 & 0.02 & $\mathrm{~F}$ & 3.92 & 0.56 & 0.0 \\
\hline CD & 874 & 1641 & 4 & 1.41 (0.85 to 2.36$)$ & 1.32 & 0.19 & $\mathrm{~F}$ & 3.91 & 0.27 & 23.0 \\
\hline \multicolumn{11}{|l|}{ CC vs GG } \\
\hline Overall & 1498 & 1656 & 6 & 1.54 (1.09 to 2.24$)$ & 2.43 & 0.01 & $\mathrm{~F}$ & 7.30 & 0.20 & 32.0 \\
\hline Asian & 286 & 524 & 3 & 1.74 (1.02 to 2.97$)$ & 2.04 & 0.04 & $\mathrm{~F}$ & 1.72 & 0.42 & 0.0 \\
\hline European & 1212 & 1132 & 3 & $1.42(0.89$ to 2.24$)$ & 1.49 & 0.14 & $\mathrm{~F}$ & 5.38 & 0.07 & 63.0 \\
\hline UC & 852 & 1656 & 6 & $1.64(1.12$ to 2.41$)$ & 2.52 & 0.01 & $\mathrm{~F}$ & 3.88 & 0.57 & 0.0 \\
\hline CD & 646 & 1219 & 4 & $1.44(0.86$ to 2.40$)$ & 1.40 & 0.16 & $\mathrm{~F}$ & 4.68 & 0.20 & 36.0 \\
\hline \multicolumn{11}{|l|}{ GC vs GG } \\
\hline Overall & 2003 & 1972 & 6 & 1.40 (1.00 to 1.95$)$ & 1.97 & 0.05 & $\mathrm{R}$ & 18.46 & 0.002 & 73.0 \\
\hline Asian & 401 & 810 & 3 & $1.02(0.79$ to 1.31$)$ & 0.14 & 0.89 & $F$ & 1.01 & 0.60 & 0.0 \\
\hline European & 1602 & 1465 & 3 & 1.21 (0.72 to 2.03$)$ & 0.73 & 0.47 & $\mathrm{R}$ & 12.77 & 0.002 & 84.0 \\
\hline UC & 1157 & 2223 & 6 & $1.20(1.02$ to 1.40$)$ & 2.20 & 0.03 & $\mathrm{~F}$ & 9.64 & 0.09 & 48.0 \\
\hline CD & 846 & 1599 & 4 & 1.09 (0.69 to 1.74$)$ & 0.39 & 0.70 & $\mathrm{R}$ & 9.13 & 0.03 & 67.0 \\
\hline \multicolumn{11}{|l|}{ C vs $\mathrm{G}$} \\
\hline Overall & 4168 & 4576 & 6 & 1.17 (0.91 to 1.50$)$ & 1.25 & 0.21 & $\mathrm{R}$ & 18.47 & 0.002 & 73.0 \\
\hline Asian & 862 & 1578 & 3 & 1.17 (0.96 to 1.43$)$ & 1.54 & 0.12 & $\mathrm{~F}$ & 1.36 & 0.51 & 0.0 \\
\hline European & 3306 & 2998 & 3 & $1.20(0.72$ to 2.01$)$ & 0.70 & 0.49 & $\mathrm{R}$ & 17.04 & 0.0002 & 88.0 \\
\hline UC & 2420 & 4576 & 6 & 1.24 (1.09 to 1.41$)$ & 3.20 & 0.001 & $\mathrm{~F}$ & 9.91 & 0.08 & 50.0 \\
\hline CD & 1748 & 3282 & 4 & $1.16(0.73$ to 1.83$)$ & 0.63 & 0.53 & $\mathrm{R}$ & 12.78 & 0.005 & 77.0 \\
\hline
\end{tabular}

CD, Crohn's disease; F, fixed-effects model; R, random-effects model; UC, ulcerative colitis. 


\begin{tabular}{|c|c|c|c|c|c|}
\hline Study or subgroup & $\mathrm{OR} 95 \% \mathrm{CI}$ & $\mathrm{CC}$ vs $\mathrm{GC}+\mathrm{GG}$ & $\mathrm{OR} 95 \% \mathrm{CI}$ & $\mathrm{C}$ vs GG & \\
\hline A 1. Asian & & & B & & \\
\hline Fei & $2.99(1.22,7.36)$ & & $2.85(1.13,7.20)$ & & \\
\hline Nohara & $1.25(0.56,2.80)$ & & $1.33(0.59,3.02)$ & & \\
\hline Shiroeda & $1.36(0.42,4.39)$ & & $1.30(0.40,4.26)$ & & \\
\hline Subtotal $(95 \% \mathrm{CI})$ & $1.75(1.04,2.95)$ & & $1.74(1.02,2.97)$ & & \\
\hline Heterogeneity: (I-sq & uared $=9 \%, P=0.33$ ) & & (I-squared $=0 \%, \mathrm{P}=0.42$ ) & & \\
\hline 2. European & & & & & \\
\hline Griga & $0.50(0.16-1.51)$ & & $0.45(0.15 .138)$ & & \\
\hline Oliver & $1.74(1.00,3.02)$ & & $1.88(1.08,3.27)$ & & \\
\hline Przybyl owska & $2.52(0.22,28.15)$ & & $3.00(0.27,33.76)$ & & \\
\hline Subtotal $(95 \% \mathrm{CI})$ & $1.36(0.86,2.15)$ & & $1.42(0.89 .2 .24)$ & & \\
\hline Heterogeneity:(I-squ & uared $=52 \%, \mathrm{P}=0.12$ ) & & (I-squared $=63 \%, \mathrm{P}=0.20$ ) & & \\
\hline Total $(95 \% \mathrm{CI})$ & $1.51(1.07,2.14)$ & & $1.54(1.09,2.19)$ & $\bullet$ & \\
\hline Heterogeneity: (I-sq & quared $=26 \%, \mathrm{P}=0.24$ ) & & $(\mathrm{I}-\mathrm{squared}=32 \%, \mathrm{P}=0.07)$ & & \\
\hline & $\begin{array}{ll}1 & 0.01 \\
0.1\end{array}$ & 10 & $0.01 \quad 0.1$ & 10 & 100 \\
\hline Study or subgroup & OR $95 \% \mathrm{CI}$ & $\mathrm{CC}$ vs $\mathrm{GC}+\mathrm{GG}$ & OR $95 \% \mathrm{CI}$ & $\mathrm{CC}$ vs GG & \\
\hline C 1. UC & & & $\mathrm{D}$ & & \\
\hline Fei & $3.07(1.12,7.75)$ & & $2.92(1.12,7.58)$ & & \\
\hline Griaga & $0.63(0.14,2.81)$ & & $0.59(0.13,2.63)$ & & \\
\hline Nohara & $1.25(0.56-2.80)$ & & $1.33(0.59,3.02)$ & & \\
\hline Oliver & $1.74(0.92,3.26)$ & 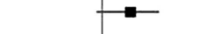 & $1.89(1.00,3.56)$ & & \\
\hline Przybyowska & $2.14(0.13,34.83)$ & & $2.61(0.16,42.71)$ & & \\
\hline Shiroeda & $1.36(0.42,4.39)$ & & $1.30(0.40,4.26)$ & & \\
\hline Subtotal(95\%CI) & $1.60(1.09,2.35)$ & & $1.64(1.12,2.41)$ & & \\
\hline Heterogeneity: (I-s & squared $=0 \%, P=0.56$ ) & & (I-squared $=0 \%, \mathrm{P}=0.57$ ) & & \\
\hline 2. $C D$ & & & & & \\
\hline Fei & $2.58(0.49,13.43)$ & & $2.47(0.45,13.67)$ & & \\
\hline Griga & $0.41(0.09,1.80)$ & - & $0.37(0.08,1.62)$ & & \\
\hline Oliver & $1.74(0.93,3.25)$ & $\because-$ & $1.87(1.00,3.50)$ & & \\
\hline Pyrzybylowska & $3.05(0.19,49.89)$ & & $3.54(0.21,58.34)$ & & \\
\hline Subtotal $(95 \% \mathrm{CI})$ & $1.41(0.85,2.36)$ & & $1.44(0.86,2.40)$ & & \\
\hline Heterogeneity: (I-s & squared $23 \%, \mathrm{P}=0.27$ ) & & (I-squared $=36 \%, \mathrm{P}=0.20)$ & & \\
\hline Total $(95 \% \mathrm{Ci})$ & $1.53(1.13,2.08)$ & & $1.57(1.15,2.13)$ & $\Delta$ & \\
\hline Heterogeneity: (I-s & squared $=0 \% n . \frac{P=0.55)}{1}$ & & (I-squared $=\frac{0 \%, \mathrm{P}=0.48)}{\mathrm{T}}$ & & 1 \\
\hline
\end{tabular}

Figure 2 Forest plot of inflammatory bowel disease risk associated with migration inhibitory factor MIF-173 G/C polymorphism for different genetic model. (A) $C C$ vs $G G+G C$ and (B) $C C$ vs $G G$ for ethnicity; (C) $C C$ vs $G C+G G$ and (D) $C C$ vs $G G$ for ulcerative colitis (UC) and Crohn's disease (CD).

2.36, $\mathrm{p}=0.19$ for heterogeneity) or $\mathrm{CC}$ vs $\mathrm{GG}(\mathrm{OR}=1.44$, CI 0.86 to $2.40, \mathrm{p}=0.16$ for heterogeneity).

Although IBD includes UC and CD, the cases of IBD in Asians included in our data were mainly UC, and only 15 cases were CD. This may influence the accuracy of the meta-analysis results in the subgroup of ethnicity. Therefore, we analysed the association of the MIF-173 $\mathrm{G} / \mathrm{C}$ polymorphism with $\mathrm{UC}$ in the subgroup of ethnicity. As shown in figure $3 \mathrm{~A}$, a significant difference was observed in Asians for CG vs GC+GG (OR=1.73, CI 1.02 to $2.94, \mathrm{p}=0.04$ for heterogeneity). Similar to previous results, no significant difference was observed in Europeans for CG vs GC+GG (OR=1.47, CI 0.85 to 2.55, $\mathrm{p}=0.17$ for heterogeneity).

\section{Sensitivity analyses and publication bias}

Sensitivity analyses were performed to assess the influence of each individual study on the pooled ORs by the systematic omission of the individual studies from the analyses. The corresponding pooled OR was not materially altered. Begg's funnel plot and the Egger's test were performed to assess the publication bias of the literature. As shown in figure $3 \mathrm{~B}$, the shape of the funnel plot did not reveal obvious asymmetry. The
Egger's test was used to provide statistical evidence of funnel plot symmetry. The results still did not suggest any evidence of publication bias (data not shown).

\section{DISCUSSION}

The human MIF gene, which is located on chromosome 22q11.2, is short; it is composed of three exons of 205 , 173 and $183 \mathrm{bp}$ and two introns of 189 and 95 bp. ${ }^{12} 2728$ Four polymorphisms of the human MIF gene have been reported, including a 5-8 CATT tetranucleotide repeat at position -794 CATT $_{(5-8)}$ and 3 single-nucleotide polymorphisms at positions MIF-173 G/C, +254 T/C and $+656 \mathrm{C} / \mathrm{G}{ }^{1314}{ }^{29}$ However, in IBD, studies on MIF gene polymorphisms have mainly focused on the MIF-173 G/C SNP. Therefore, in this meta-analysis, we mainly discussed the association of the MIF-173 G/C gene polymorphism with the susceptibility to IBD.

In the current meta-analysis of six studies consisting of 2084 cases and 2288 controls, we found that the MIF-173 $\mathrm{G} / \mathrm{C}$ gene polymorphism is significantly associated with IBD susceptibility in the recessive model (OR 1.5) and codominant model (OR 1.54), while no significant associations were found in the dominant model or the 


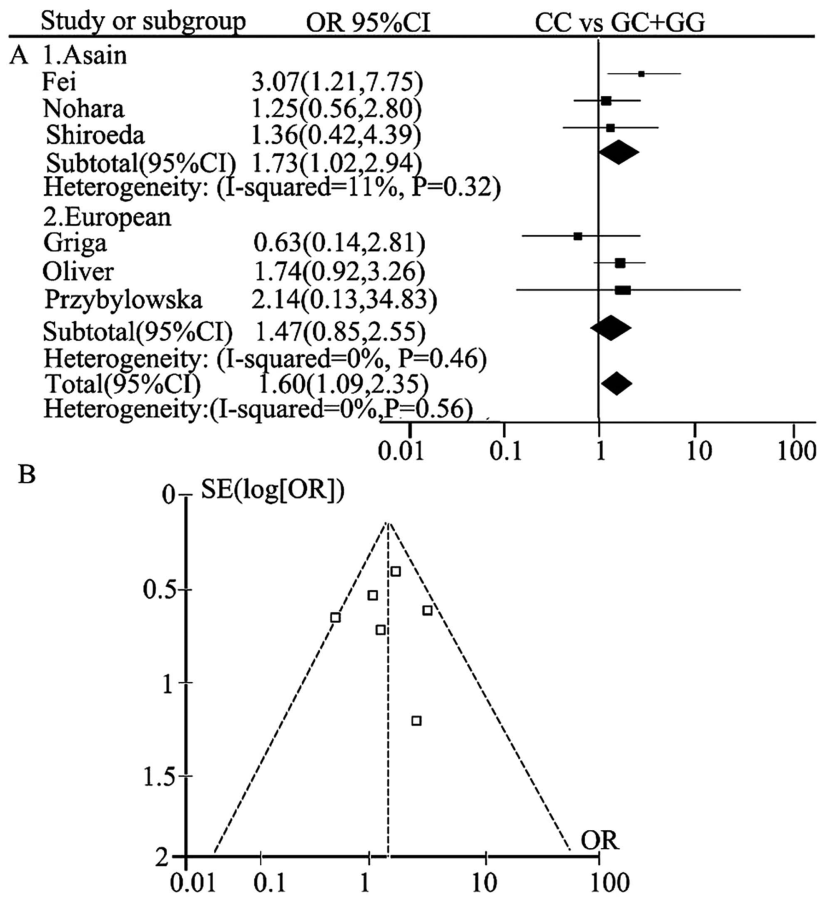

Figure 3 (A) Forest plot of ulcerative colitis (UC) risk associated with migration inhibitory factor (MIF)-173 G/C polymorphism for $\mathrm{CC}$ vs $\mathrm{GG}+\mathrm{GC}$ in Asian and European; (B) Begg's funnel plot of the MIF-173 gene polymorphism and inflammatory bowel disease risk for combined CC vs GC+GG.

allelic model. The results indicated that the MIF-173 $\mathrm{G} / \mathrm{C}$ polymorphism was a conspicuous high-risk factor for developing IBD in the overall study population.

The second finding of this meta-analysis is that in the subgroup of ethnicity, the MIF-173 G/C gene polymorphism was significantly different in Asians in the recessive (OR 1.75) and codominant (OR 1.74) models, while no significant differences were found in Europeans. This finding is consistent with previous results that a gene polymorphism does not have the same effect in different ethnicities. For example, the TNF- $\alpha 308 \mathrm{~A}$ gene polymorphism plays an important role in Asian populations, while no conclusive data on this association exist in European patients. ${ }^{30}$ In addition, the best studied genetic variant, a nucleotide oligomerisation domain 2 (NOD2) polymorphism, is present in up to $20 \%$ of patients with $\mathrm{CD}$ in White and Jewish populations, but major disease-associated variants have not been detected in individuals of Asian descent with CD. ${ }^{3132}$

The third finding of this meta-analysis is that in the subgroup of the two diseases, UC and CD, significant differences were found in the recessive (OR 1.60) and codominant (OR 1.64) model for UC, while no difference was found in the recessive or codominant model for CD. This result suggests that the MIF-173 G/C polymorphism seems to be a risk factor for UC but not for the CD. However, in another study, Zhang et $a l^{33}$ confirmed that the peroxisome proliferator-activated receptor $\gamma(\mathrm{PPAR} \gamma)$ AlaAla genotype is a protective factor against the development of $\mathrm{CD}$, especially in the European Caucasian population, while no significant association was found in the development of UC. Both of these results indicated that the gene polymorphism has different effects in different diseases.

To further determine whether the MIF-173 gene polymorphism for UC was different in different ethnicities, we performed a meta-analysis of UC in the subgroup of ethnicity. A significant difference was found in the recessive model (OR 1.73) in Asians, while no significant difference was found in Europeans. Although only three studies were included in the subgroup analysis, they all have high quality. So the results in the subgroup analysis were credible.

In addition, two similar studies had been published. However, compared with the two studies, ${ }^{34} 35$ our study has the special strength. First, it has been claimed that the studies included in the meta-analysis should not be deviated from HWE. So in our study we did not include the study from India. ${ }^{23}$ Second, in our study, we analysed MIF polymorphism and the risk of UC in Asian and European populations. Since the results of MIF polymorphism and the risk of IBD may be influenced by the bias because the number of $\mathrm{CD}$ in Asians was low. However, the present meta-analysis had several limitations that must be taken into consideration. First, the number of available studies that could be included in this meta-analysis was moderate. Therefore, the results could be influenced by factors such as random error. Therefore, next we will focus on research on the association between gene polymorphisms and IBD in our hospitals. Second, the overall outcomes were based on individual unadjusted ORs, while a more precise evaluation should be adjusted by other potentially suspected factors, including age, sex and environmental factors.

In summary, the current meta-analysis suggested that the MIF-173 G/C polymorphism contributed to the susceptibility of IBD. In the subgroups of ethnicity and UC and $\mathrm{CD}$, the result suggested that this polymorphism was more significant for UC in Asians.

\section{Author affiliations}

${ }^{1}$ Department of Gastroenterology, Xinqiao Hospital, Third Military Medical University, Chongqing, China

${ }^{2}$ Department of Epidemiology, Third Military Medical University, Chongqing, China

${ }^{3}$ The Evidence Based Medicine and Clinic Epidemiology Center, Third Military Medical University, Chongqing, China

${ }^{4}$ Chongqing Key Laboratory for Diseases Proteomics, Southwest Hospital, Third Military Medical University, Chongqing, China

Acknowledgements The authors would like to thank American Journal of Experts for providing help in the writing and polishing.

Contributors N-BH and YFH contributed to conception and design, acquisition of the data or analysis and interpretation of the data. $\mathrm{N}-\mathrm{BH}$ and $\mathrm{XY}$ were involved in acquisition of the data. N-BH, YFH, GL and $\mathrm{YZ}$ were involved in analyses and interpretation of the data. $\mathrm{N}-\mathrm{BH}$ and $\mathrm{XY}$ drafted the article.

Funding This work was funded by the Chongqing Science Fund for Distinguished Young Scholars (CSTC, 2009BA5045) and the National Natural Science Foundation of China (NSFC No. 81202220). 
Competing interests None.

Provenance and peer review Not commissioned; externally peer reviewed.

Data sharing statement No additional data are available.

Open Access This is an Open Access article distributed in accordance with the Creative Commons Attribution Non Commercial (CC BY-NC 3.0) license, which permits others to distribute, remix, adapt, build upon this work noncommercially, and license their derivative works on different terms, provided the original work is properly cited and the use is non-commercial. See: http:// creativecommons.org/licenses/by-nc/3.0/

\section{REFERENCES}

1. Baumgart DC, Carding SR. Inflammatory bowel disease: cause and immunobiology. Lancet 2007;369:1627-40.

2. Loftus EV Jr. Clinical epidemiology of inflammatory bowel disease: incidence, prevalence, and environmental influences. Gastroenterol 2004;126:1504-17.

3. van Lierop PP, Samsom JN, Escher JC, et al. Role of the innate immune system in the pathogenesis of inflammatory bowel disease. $J$ Pediatr Gastroenterol Nutr 2009;48:142-51.

4. Bacher M, Meinhardt A, Lan HY, et al. Migration inhibitory factor expression in experimentally induced endotoxemia. Am J Pathol 1997; 150:235-46.

5. Baugh JA, Bucala R. Macrophage migration inhibitory factor. Crit Care Med 2002;30:S27-35

6. Rosado Jde D, Rodriguez-Sosa M. Macrophage migration inhibitory factor (MIF): a key player in protozoan infections. Int $\mathrm{J} \mathrm{Biol} \mathrm{Sci}$ 2011;7:1239-56.

7. Gregersen PK, Bucala R. Macrophage migration inhibitory factor, MIF alleles, and the genetics of inflammatory disorders: incorporating disease outcome into the definition of phenotype. Arthritis Rheum 2003:48:1171-6.

8. Morand EF, Bucala R, Leech M. Macrophage migration inhibitory factor: an emerging therapeutic target in rheumatoid arthritis. Arthritis Rheum 2003:48:291-9.

9. Lan HY, Mu W, Yang N, et al. De Novo renal expression of macrophage migration inhibitory factor during the development of rat crescentic glomerulonephritis. Am J Pathol 1996;149:1119-27.

10. Lan HY, Yang N, Nikolic-Paterson DJ, et al. Expression of macrophage migration inhibitory factor in human glomerulonephritis. Kidney Int 2000;57:499-509.

11. de Jong YP, Abadia-Molina AC, Satoskar AR, et al. Development of chronic colitis is dependent on the cytokine MIF. Nat Immunol 2001;2:1061-6.

12. Renner $\mathrm{P}$, Roger $\mathrm{T}$, Calandra $\mathrm{T}$. Macrophage migration inhibitory factor: gene polymorphisms and susceptibility to inflammatory diseases. Clin Infect Dis 2005;41(Suppl 7):S513-19.

13. Donn RP, Shelley E, Ollier WE, et al. A novel 5'-flanking region polymorphism of macrophage migration inhibitory factor is associated with systemic-onset juvenile idiopathic arthritis. Arthritis Rheum 2001;44:1782-5.

14. Baugh JA, Chitnis S, Donnelly SC, et al. A functional promoter polymorphism in the macrophage migration inhibitory factor (MIF) gene associated with disease severity in rheumatoid arthritis. Genes Immun 2002;3:170-6.

15. Griga T, Wilkens $\mathrm{C}$, Wirkus $\mathrm{N}$, et al. A polymorphism in the macrophage migration inhibitory factor gene is involved in the genetic predisposition of Crohn's disease and associated with cumulative steroid doses. Hepatogastroenterol 2007;54:784-6.
16. Fei BY, Lv HX, Yang JM, et al. Association of MIF-173 gene polymorphism with inflammatory bowel disease in Chinese Han population. Cytokine 2008;41:44-7.

17. Oliver J, Marquez A, Gomez-Garcia M, et al. Association of the macrophage migration inhibitory factor gene polymorphisms with inflammatory bowel disease. Gut 2007;56:150-1.

18. Little J, Bradley L, Bray MS, et al. Reporting, appraising, and integrating data on genotype prevalence and gene-disease associations. Am J Epidemiol 2002;156:300-10.

19. Whiting PF, Weswood ME, Rutjes AW, et al. Evaluation of QUADAS a tool for the quality assessment of diagnostic accuracy studies. BMC Med Res Methodol 2006;6:9.

20. Mantel N, Haenszel W. Statistical aspects of the analysis of data from retrospective studies of disease. J Natl Cancer Inst 1959;22:719-48.

21. DerSimonian R, Laird N. Meta-analysis in clinical trials. Control Clin Trials 1986;7:177-88.

22. Egger M, Davey Smith G, Schneider M, et al. Bias in meta-analysis detected by a simple, graphical test. World J Gastroentero 1997:315:629-34.

23. Sivaram G, Tiwari SK, Bardia A, et al. Macrophage migration inhibitory factor, Toll-like receptor 4 , and CD14 polymorphisms with altered expression levels in patients with ulcerative colitis. Hum Immunol 2012;73:201-5.

24. Przybylowska K, Mrowicki J, Sygut A, et al. Contribution of the $-173 \mathrm{G} / \mathrm{C}$ polymorphism of macrophage migration inhibitory factor gene to the risk of inflammatory bowel diseases. Pol Przegl Chir 2011;83:76-80.

25. Shiroeda H, Tahara T, Nakamura M, et al. Association between functional promoter polymorphisms of macrophage migration inhibitory factor (MIF) gene and ulcerative colitis in Japan. Cytokine 2010;51:173-7.

26. Nohara H, Okayama N, Inoue N, et al. Association of the $-173 \mathrm{G} / \mathrm{C}$ polymorphism of the macrophage migration inhibitory factor gene with ulcerative colitis. J Gastroenterol 2004;39:242-6.

27. Paralkar V, Wistow G. Cloning the human gene for macrophage migration inhibitory factor (MIF). Genomics 1994;19:48-51.

28. Budarf $\mathrm{M}, \mathrm{McD}$ onald $\mathrm{T}$, Sellinger $\mathrm{B}$, et al. Localization of the human gene for macrophage migration inhibitory factor (MIF) to chromosome 22q11.2. Genomics 1997;39:235-6.

29. Donn R, Alourfi Z, De Benedetti F, et al. Mutation screening of the macrophage migration inhibitory factor gene: positive association of a functional polymorphism of macrophage migration inhibitory factor with juvenile idiopathic arthritis. Arthritis Rheum 2002:46:2402-9.

30. Yun J, Xu CT, Pan BR. Epidemiology and gene markers of ulcerative colitis in the Chinese. World J Gastroenterol 2009;15:788-803.

31. Hugot JP, Chamaillard M, Zouali $\mathrm{H}$, et al. Association of NOD2 leucine-rich repeat variants with susceptibility to Crohn's disease. Nature 2001:411:599-603.

32. $\mathrm{Ng} \mathrm{SC}$, Tsoi KK, Kamm MA, et al. Genetics of inflammatory bowel disease in Asia: systematic review and meta-analysis. Inflamm Bowel Dis 2012;18:1164-76.

33. Zhang ZF, Yang N, Zhao G, et al. Association between the Pro12Ala polymorphism of peroxisome proliferator-activated receptor gamma 2 and inflammatory bowel disease: a meta-analysis. PLOS ONE 2012;7:e30551

34. Shen $\mathrm{Y}$, Guo S, Yang T, et al. The $-173 \mathrm{G} / \mathrm{C}$ polymorphism of the MIF gene and inflammatory bowel disease risk: a meta-analysis. Int $J$ Mol Sci 2013;14:11392-401.

35. Zhang $\mathrm{H}, \mathrm{Ma} \mathrm{L}$, Dong $\mathrm{LQ}$, et al. Association of the macrophage migration inhibitory factor gene-173G/C polymorphism with inflammatory bowel disease: a meta-analysis of 4296 subjects. Gene 2013;526:228-31. 